\title{
The EFL Students' Problems in Answering the Test of English as a Foreign Language (TOEFL): A Study in Indonesian Context
}

\author{
Murni Mahmud \\ FBS UNM Makassar, Indonesia
}

\begin{abstract}
The focus of this paper is to explore the students' problems in answering the TOEFL (Test of English as a Foreign Language). TOEFL is a type of language testing to reveal the students' English proficiency. This is a descriptive study based on in-depth semi-structured interview and classroom observation. The subject of this research was the students of Graduate Program at one state university in Makassar, Indonesia. This study took three classes as sample, namely one from English education department, one from Social Science, and one from Natural Science. To gain data, the three classes were observed and twelve (12) representatives of the three classes were interviewed. Findings showed that the main problems of the students in answering the TOEFL test were due to several conflicting reasons, such as fewer basic skills, less practice, less motivation, and students' individual differences such as age and social status.
\end{abstract}

Index Terms-TOEFL, TOEFL preparation course, language testing, language teaching, and English proficiency

\section{INTRODUCTION}

The need to master English is absolutely very crucial. Functioning as international language for communication, people are expected to know English either for daily communication or for public use. The functions of English as a major tool for communication have been globally recognized. English is important not only in education, but also in other public sectors in which people are interacting.

English is used widely in the world and studied as a foreign language or as a second language in several countries (Erdem-Keklik, 2011; Sindhedkar, 2012). A study by Sindkhedkar, for example, (2012, p. 2) confirmed the position of English language as a major tool for communication in India and states that English "occupies the position of associate official language" and widely used as "a link language in offices and among the educated people". It is further stated that English is "not only a compulsory subject at school, college and university but is also the medium of instruction to the large extent". English has functioned as "the language of science and technology". Erdem-Keklik (2011) also mentioned that English is the most popular foreign language taught in Turkish schools.

Therefore, English becomes important subjects either in schools or in universities in every country. Indonesia, a country in Southeast Asia, also sets the important roles of English education. This brings the ideas that English should be taught from Junior high Schools to Universities, including in state universities in Makassar, South Sulawesi, Eastern Indonesia.

For the sake of developing and maintaining the English capabilities, plenty of efforts are required in teaching English. The success in teaching English is influenced by many factors, such as the teachers, materials, and methods. That is the roles of the teachers in the classroom to integrate good materials and methods. In addition, factors from students should be highly considered. That is also the roles of the teachers to organize teaching materials and methods that are suitable with the needs and interests of the students.

One of the aspects in the teaching process is the language testing. Issues in language testing had been the focus of research in educations in different countries and different contexts. Pan (2009) examined the roles of test as an exit requirement in China and Fahim et al. (2010) explored the test takers' ability in reading test of the TOEFL in relation to critical thinking. Another study by Zareva (2005) examined the new format for the TOEFL test. Arabsarhangi and Noroozi (2014) studied reading comprehension test types in relation to self awareness and learners' performance. All of these studies indicate the pivotal functions of good language testing as instruments to measure the students' English proficiency. For that reason, it is necessary for the teachers to create reliable testing for the language proficiency of the students in order to evaluate the achievement of the students.

One of the types of language testing is TOEFL, which stands for 'Test of English as a Foreign Language'. This test is highly recognized as a standard language testing in English language and had been "internationally recognized and respected" (Warfield et al., 2013, p. 196). The grade of the TOEFL is mostly used as indicator in academic life around the world. For example, when students want to continue their study to foreign countries, the university asks the applicants to submit their TOEFL grade as indicator of their English language proficiency. Studying in foreign countries definitely demands high English proficiency level that can be seen from the TOEFL grade. 
In Indonesia, the TOEFL test is originally conducted by English Language System (ELS), a specific institution for TOEFL Test, known as Institutional TOEFL. The university may also administer a TOEFL-like or a TOEFL-equivalent test, or a TOEFL prediction, such as by the center of language studies or by the language laboratory within the university. This kind of TOEFL test is locally administered by the university, and only used for internal usages in order to examine the students' English proficiency.

In Indonesia, particularly in Makassar, the TOEFL test is highly recommended for students who want to continue their education to higher level, for example, from undergraduate level to graduate level. The test is also used for public usages such as to get promotion to higher level of job. Since the test is measuring English proficiency covering many different skills such as listening, reading, grammar, writing, and speaking, many students find it difficult to do the test. In fact, in Makassar, taking TOEFL test is considered difficult. Consequently many test takers failed the test and did not reach the standard passing grade.

This paper examines the students' problems in answering the TOEFL test in one state university in Makassar. Like other universities in Indonesia, this university also has a specific institution for administering the English test proficiency such as TOEFL, TOEIC, and IELTS. In the Graduate program, TOEFL Test is used as an entrance test to be accepted as new students. The test also becomes the requirement for the final exam. Students who want to take their final exam for their thesis are required to pass the standard grade, for example, for $>400$ for non-English students and $>476$ for English students. To assist students, TOEFL Preparation courses are also available. Nevertheless, the fact shows that many students failed the tests.

The main question brought into discussion in this paper is what are the problems encountered by the students in answering the TOEFL Test? Findings from this study are very beneficial as input for the teaching of TOEFL, especially in the TOEFL Preparation courses. Exploring problems the students have may become guidelines in managing and preparing the good TOEFL lesson project.

\section{RELATED LITERATURE}

Kafafi defined assessment as an 'indicator of learners' acquisition of knowledge and of the teachers' quality of teaching" (2012, p. 101). It is "an integral part of providing a quality teaching experience for the adult learners, their long life learning process, and their participation in the community and the national economy" (Kafafi, 2012, p. 105). In addition, AERA et al. formulated that "assessment is any systematic procedure for collecting information that can be used to make inferences about the characteristics of people or objects" (cited in Reynolds et al, 2006, p. 3). It is further stated that assessment is "an integral component of the teaching process and it provides information that both enhances instruction and promotes learning" (Reynolds et al., 2006, p. 3).

Having a good assessment can be by organizing a good and reliable test. Reynolds et al (2006, p. 3) defined a test as "a device or procedure in which a sample of an individual's behavior is obtained, evaluated, and score using standardized procedures". It is "a method of collecting information and therefore one set of tools of assessment" (Reynolds et al, 2006, p. 3).

Thus, the results of a good assessment and reliable test will give implication about the success of the students and the teachers in the teaching process. TOEFL which stands for Test of English as a Foreign Language is a standard test for measuring students' English language capabilities. There are two types of TOEFL Test, namely Paper-Based Test(PBT) and Computer Based Test (CBT). The most common type of the test is the PBT, which was also used by the subject of this research. In the test, the students are required to master three important skills in English, namely Listening Comprehension, Structure and Written Expression, and Reading Comprehension. There are also tests for Speaking and Writing. There is also a scoring system for the TOEFL test. The minimum score is 216 whereas the highest score is 676 (Philips, 2001).

\section{Methods OF THE STUDY}

This study was conducted in one of the state universities in Makassar, South Sulawesi, Eastern part of Indonesia in 2013. The study focused on the students of Graduate Program who took TOEFL Test as the requirement for finishing their study. After being successful to be accepted as students, the results of the TOEFL Test in the entrance test became the basic guidelines for administering the TOEFL Preparation course. The TOEFL certificate would be issued for the students who were able to reach the passing grade, which then became the requirement for them to finish their study. If they did not pass the TOEFL test, their final exam would be suspended. The passing grades were 426> for Non English Program and 476> for English Program. Since it was locally used in the Graduate Program, the TOEFL used was not Institutional TOEFL. The TOEFL-like or the TOEFL Prediction was used instead whose materials were taken from the TOEFL Preparation Books (Philips 2001).

The Graduate program had the language laboratory that conducted the test (TOEFL-like or prediction TOEFL) and also conducted the TOEFL Preparation Course. In 2013, there were 30 classes which were conducted by the language laboratory covering different study programs. The programs were English Education, Non-English Program (Indonesian Language and Social Science (Economy, Geography, History, Educational Management, Early Childhood Education, 
Educational Research, Sociology, Sports, and Arts) and Natural Science (Mathematics, Biology, Physics, Chemistry, and Technology). Each class consisted of 15 to 20 students.

For this study, three classes were taken as sample (one from English department, and two from non-English department, namely one social science class and one natural science class). To collect data, I observed these three classes. I also conducted in depth semi-structured interview to representatives of these three classes. There were twelve students (four for each class) who were interviewed. These respondents were chosen based on the frequency they took TOEFL test and their obtained scores which had not reached the passing grade. Respondents had taken the TOEFL Preparation Course and had taken tests for many times. Some of the respondents had to take remedial course and failed the tests for many times. The main focus was asking their major problems in answering the TOEFL Test.

\section{FINDINGS}

Based on the observation on the three classes of TOEFL Preparation and the intensive interview among the twelve respondents from these three classes, it was found that most of the students found difficulties in answering the TOEFL Test and therefore failed the tests. Some respondents had to repeat the tests for many times but failed. The respondents were then interviewed to find out what problems they found in answering the TOEFL Test. Some of the problems were as follows:

\section{A. Fewer Basic Skills}

One of the main problems encountered by the respondents was that they had no basic skills in English. Some respondents stated their reasons as follows:

"Kami tidak pernah belajar bahasa Inggris. Kami tiba-tiba harus tahu bahasa Inggris"

(We never studied English. We accidentally had to learn English)

"Kami tidak ada dasar sama sekali"

(We did not have very basic English)

"Bahasa Inggris susah, saya tidak mengerti artinya"

(English is difficult, I do not understand the meaning)

"TOEFL ini adalah sesuatu yang baru. Kami belum pernah mengikutinya"

(TOEFL is something new for us. We have never joined that before)

"Jangankan menjawab soal TOEFL, bercakap saja saya tidak bias"

(Even talking in English I did not know, how could I answer the TOEFL Test)

From the above comments, it can be stated that the difficulties of the respondents in answering the TOEFL test were due to their less basic skills. Respondents stated that even speaking in English they were not able to, whereas answering TOEFL Test was difficult because the test was testing their ability in listening, grammar, and reading.

As observed in the class, respondents demonstrated low capabilities in understanding English grammar. Indeed, the materials should be started from the very basic level such as subject pronoun, object pronoun, verb forms, etc. The problems existed since in the TOEFL materials, the students were expected to know more about more complicated problems such as subject and verb agreements, parallel structures, etc. Therefore, teachers sometimes spent a lot of time explaining very basic grammar and did not have more time to practice for other sections in the TOEFL test.

In addition, they said that TOEFL Test was something new for them, especially from non-English program. TOEFL test was a new thing in their academic life. They stated that they never joined it in their undergraduate program. This comment was mostly stated by those who came from Social science, especially if they came from outer part of Makassar.

The interesting things came out from the English students whose basic was English and majoring in English Department. Since that was their major, they were expected to do the test properly and got good results. In fact, several students did the test for many times. Some English students had to take the test 8 times in order to pass the test. One of their difficulties was due to the many limited time in the test. In the listening comprehension, for example, they sometimes lost the ideas before coming to the next questions. One of the respondents from English education department stated as follows:

"Saya tidak bisa mendengar dan membaca dengan baik dalam waktu singkat"

(I could not listen and read carefully in the short time)

The problems were then they had to answer all of the three sections in the test during the allocated time. The score for each part would be balanced. In spite of the above problems, they still did many errors in grammar, in which high scores were expected from the part of structure and written expression. Other comments from the English department respondent were as follows:

"Saya tidak tahu, jawabannya mirip-mirip"

(I do not know, the answers looked similar)

"Saya selalu dapat soal yang susah. Bacaan di reading panjang-panjang"

(I always got difficult test. The readings are always long)

In fact, the tests had been sometimes used in the course as exercises. Nevertheless, the test remained difficult for them and they needed to repeat the test for many times. 
One of the respondents from English department had to join the test until 9 times. When asked about the problem, she said that she was less in the three skills of the TOEFL. It was also due to her less concentration. Although she had repeated the course for three times, she still had difficulties in doing the test. She finally passed the test with the score 480 in the $9^{\text {th }}$ time she took the test.

\section{B. Less Practice}

As a matter of fact, before joining the test, the course had been offered to the students in order to give them preparation. This is needed in order to make them familiar with the test and to guide them in answering the tests. As observed in the class, several students did not commit their time to the course. In the class, for example, many of them did not come to the course.

Even when they had taken the course, students showed fewer struggles. Consequently, less practice was experienced during the course. According to them, the time was very short. The course which was administered for one to two weeks intensively was not enough to solve the problems they had in the test. When the teaching was trying to last longer, for example, in three months, other problems may also come from the students since they had limited time for the course. One student was interviewed and said:

"Materi banyak sekali. Kami tidak bisa menguasai dalam waktu singkat karena kami juga sibuk dengan pekerjaan kami yang lain"

(there are so many materials. We could not master all of things in a very short time because we are all busy with my other jobs).

Therefore, they just tried to maximize the time to learn, which was not effective and efficient. Sometimes, the students asked to shorten to duration of the course because they were very busy in their other duties as students and as officers in other places. It is important to note here that the students came from different backgrounds. Most of them had already worked as teachers or other jobs as students, and therefore, they were also busy in their other jobs outside the campus. The course that had been administered for 1 or 2 week was sometimes asked to be shortened into three days in order to suit with their job. Seeing the materials of TOEFL course which was very substantial covering many aspects of skills, it was not possible to conduct the course in only three days. Unless, they were committed to the time to learn English, They would have been more successful.

\section{Less Motivation}

Another problem encountered by the students in learning the TOEFL was their low motivation to learn. One of the respondents said,

"Untuk apa kita belajar TOEFL, itu bukan jurusan kami"”

(what is the use of learning TOEFL, that is not our major)

This shows that the students had low fighting spirit to learn TOEFL since that was not their major (program). This statement was sometimes said by the Social science students, whose major was not English and never learned English. Indeed, they sometimes asked the questions: "kenapa kami dipersulit" (why did the test make us difficult). They sometimes said that the test was just trying to hinder their study and they tended to see that the test was meant to slow the process in finishing their study.

The surprising statement was from English student, who was trying to join the test for three times but not pass and did not want to join the course. He said:

"Saya orang kantoran, saya tidak membutuhkan bahasa Inggris, apalagi TOEFL di tempat kerja saya"

(I work in the office, I do not need English especially TOEFL in my work place)

These ideas were sometimes influenced by the notion about formality of the test and the course. Another respondent said:

"Tes dan kursusnya kan hanya formalitas saja, jadi ikut saja, pasti akan lulus"

(The test and the course are only the formality, so just join, then you will absolutely pass)

This becomes the difficulties in administering the test and the course since there has been in their mind about the formality of the test and the course. One of the respondents said:

"Ini tes yang kedua, belum lulus, nanti yang ketiga, pasti sudah dibantu"

(This is the second test, not pass yet, after the third, (I) will be helped of course)

Usually students were expected to be helped due to the problems they have and were not willing to struggle to get higher scores by themselves. Being helped above means that the respondents expected that they scores were added in order to reach the standard grade and passes. Many respondents said:

"Biar kursus berapa kali pun dan tes berapa kali pun, akan begitu-begitu terus"

(Although I took the test and the course for many times, the results were just like that)

"Bagaimana saya ini, saya sudah mau ujian, tapi saya belum lulus TOEFL. Tolong saya dibantu saja"

(How about me, I want to take my final exam now, but I haven't passed yet, so just help me (by adding my score))

In addition, several students who were actually required to join the course asked if they could only pay for the course and then they would be helped in the tests in order to pass. In that way, they get the certificate and can pursue to their final exam. Therefore, they wanted to take the course not for improving their English but for gaining the certificate only for finishing their study. One of the respondents asked: 
"Kalau saya ikut kursus, apakah sudah pasti lulus?"

(If I joined the course, would I automatically pass?)

This comment implied that students just wanted to take a course only if there was a guarantee to pass the test. In other word, they joined the course not to learn but only to make it as a guarantee because they had paid the course. One of the respondents stated:

"Saya sudah tiga kali tes. Padahal saya juga sudah kursus"

(I have joined the test three times. I also had joined the class)

The above comments from the students remarked that they had low motivation in learning English. They would have been more successful in learning if they had high motivation. Consequently, as observed in the class, some participants in the class just tried to come, sit, and did the instruction without spirit and just to show that they came to the course, although they did not study well.

\section{Students' Individual Differences}

When they were asked about their most complicated problems in learning TOEFL, most respondents said as follows:

"Kami sudah tua"

(We are old now)

"Saya sudah berumur 45 tahun, saya sudah lambat loading"

(I am not 45 years old, I am low in remembering the materials'

"Ibu sudah kepala sekolah beberapa tahun, baru mau belajar TOEFL?,bagaimana bias"

(Madam, you have been a headmaster for years, that is now you wanted to study TOEFL? How come?)

"Saya ini pejabat. Saya tidak punya banyak waktu untuk belajar"

(I am a professional worker in my office. I do not have time to study)

This was commonly the case when they were asked why they could not answer the test well. During the course, as observed, some participants could understand some important materials and able to answer the questions and could also speak English. However, when it was the time to take the test, they already forgot all of the things because they were too old to remember all things in English. In addition, they sometimes viewed themselves as important persons due to their position in the government. Therefore, students' individual differences such as their age and social status differences contribute to their learning process and made problems in their learning.

\section{DISCUSSION}

As had been previously mentioned, it can be revealed that there were conflicting factors behind the achievement of the students in the TOEFL test. The problems were fewer basic skills, less practice, less motivation, and students' individual differences.

The first important factor was due to the less English proficiency among the students. As a matter of fact, this was influenced by the low level of English skills. Many participants said they had to study English because they must whereas they never studied it before. In other word, they had no basic English.

Therefore, there should be awareness for students to increase their English skills before enrolling to the Graduate Program. The students should bear in mind that mastering English proficiency is not only for requirements for individual competence. The students need to realize that they need English for their self-development. As stated by Pan (2009, p. 132),

"if lesson content or teaching methodology can be adapted to meet the students' interest, needs, and level of English proficiency, students may be more interested in learning English, and learning outcomes will, accordingly, much improve"

The less practice was the second problem. This was caused much by the less time committed to learn TOEFL. In this case, it is important for students to join a class to prepare them for the test. Pan $(2009$, p. 131) also noted that 'testpreparatory classes or test related instruction in regular English need to be offered so that students will have greater familiarization with the test and a clear direction as to what and how to prepare for it'.

Less motivation was the third important problem for the students. The more motivation students get, the higher the students achievement. Brown (2000, p. 60) argued that “the students' personal investment of time, effort, and attention to the second language" influence the success of students. Indeed, teachers may not be needed if the learners are motivated to perform all of the tasks in the classroom (Brown, 2000, p. 59). In line with this, Sindkhedkar (2012, p. 191) commented that it is important to motivate the students by "creating awareness amongst them regarding the importance of English and then gradually helping the student to attain his goal". In other words, teachers need to "employ various strategies aimed at enhancing student motivation" (Wong, 2013).

This less motivation was caused by many factors. One of them was their limited time committed to the learning process. If the students had committed to the course and studied well, the results of the tests may be improved. Brown (2000:60) commented as follows:

'Successful mastery of the second language will be due to a large extent of a learner's own personal 'investment' of time, effort, and attention to the second language in the form of an individualized battery of strategies for comprehending and producing the language" 
In addition, students were not highly motivated due to different perceptions of the students towards the learning process. They had different perceptions about the test and the course. They wanted to join the test not to learn but only taken for granted as a requirement. They expected that after joining the course, they can be considered to be helped in the test by upgrading their scores until reaching the passing grades.

These students' perceptions need attention and require further initiatives to ensure the good quality of the teaching. Hiew (2012:19) argued that "learners' perception towards the teaching and learning of English should be taken and reviewed seriously as it is a two-way process involving teachers and learners". Ruesch et al. (2012) had also found the relationship between perceptions and motivations of the students in learning and underscored the importance of including students' perspectives on classroom practices.

The last factor was from the students' individual differences. Findings above show that students sometimes made their age and their social status as barriers to learn hard. Age here is very crucial. Respondents stated they were too old to learn English which was difficult for them. In addition, due to their high social status outside the campus (not only as students), they sometimes felt that learning is not required anymore. They wanted to 'just pay' instead.

Referring to the above problems, it can be stated that students' individual differences could make great influence on students' achievement. Many studies had proved the important roles of social class in education (Shin, 2014; Vandrik, 2014; Gao, 2014). Vandrik's study (2014) recommended that "increased attention to social class in English language education research, teacher education, and language classrooms". Therefore it is important to consider students' background in learning and teaching.

The above findings showed that problems occurred in the students' achievement in answering the TOEFL Test were actually due to the ways the learners learn or their learning strategies. Weinstein and Meyer (1986, cited in Macaro, 2001:17) stated that learning strategies are "the behaviors and thoughts that a learner engages in during learning that are intended to influence the learners' encoding process". A study by Nikoopour et al. (2012) showed the important roles of language learning strategy as "one of the cognitive variables that are highly associated with success and achievement".

The learning strategies were influenced by many factors. In the above findings, some of the important factors are the skills of the students, motivation, cultural background, students' background including age, and students' perception about the learning. This is in line with Macaro (2001) who examined the independent variables for factors influencing the learners' background such as motivation, sex, age, background and cultural differences, aptitude, learning style, and beliefs about language learning.

Good learning strategies are important in order to achieve better results in teaching. A study by Ghavamnia et al. (2011) had proved some important variables that are related to the choice and the use of learners' strategy such as motivation, learners' belief, and proficiency. Khamkien (2010) asserted that motivation is the most significant factor affecting the choice of learning strategies besides experience in studying English and gender. Another study by Ghaedi and Jam (2014) also found a significant relationship between motivation and learning style.

In addition, students' basic skills are influential. Sugita and Takeuchi (2010) had examined this case and found that "the effectiveness of some motivational strategies varied according to students' English proficiency level". A study by Chang and Liu (2013) also found that participants with high English proficiency level displayed a significantly higher level of strategy use than their counterparts of lower and intermediate level. In this case, as found in this study, due to the low basic skills, students displayed less useful strategies to learn and tended to be pessimistic.

The above conflicting factors faced in the teaching TOEFL need further considerations from both sides: teachers and students. While the roles of the teachers are to integrate good teaching materials and strategies, students' factors should also be given great attention in order to solve the problems.

\section{CONCLUSION}

This paper has discussed the facts from the teaching of TOEFL in one of the state universities in Makassar, South Sulawesi, Indonesia. Based on the intensive interview and classroom observation, the main reasons were due to several conflicting factors, such as the less basic skills in English, less practice on the test, less motivation, and students' individual differences such as age and social status.

Findings from this study are very crucial as input for teachers in organizing and teaching TOEFL preparation Course. This teaching is very crucial as students need to take the TOEFL Test as a measurement in their English proficiency. As had been discussed above, students undertaking TOEFL test found many kinds of problems that hampered their achievement. Therefore, the process of learning and teaching in the TOEFL Preparation Course needed to be given high priority.

It can be revealed that the teaching of TOEFL for English students and Non-English students needs attention to improve further skills. The course needs not only improving the skills but also overcoming the dilemmatic problems they faced in learning TOEFL.

In order to gain better input for this study, it is suggested for further researchers to conduct related studies. One of the important aspects is to investigate the relationship of the above problems with the students' achievement in answering the TOEFL test. Are those above problems influence their achievement or are there any other factors influencing their achievement. Studies should also investigate the tests themselves whether the tests have been operated in standard 
procedures or have been reliable in testing. In addition, further research needs to be conducted to see the application of some methods by the teachers in the TOEFL Preparation course.

\section{REFERENCES}

[1] Arabsarhangi, M \& Noroozi, I. (2014). The relationship between self-awareness and learners' performance on different reading comprehension test types among Iranian EFL Elementary learners. Theory and Practice in Language Studies, 4, 4:675-685.

[2] Brown, D. H. (2000). Teaching by Principles: An Interactive Approach to Language Pedagogy. USA: Longman.

[3] Chang, C. \& Liu, H. (2013). Language learning strategy use and language learning motivation of Taiwanese EFL University students. Electronic Journal of Foreign Language Teaching, 10, 2: 196-209.

[4] Erdem-Keklik, D. (2011). Investigating differences in 7th grade Turkish students' achievement in English according to gender, type of school and some socio-demographic factors. International Journal of Arts \& Sciences, 4, 18:1-6.

[5] Fahim, M., Bagherkazemi, M, \& Alemi, M. (2010). The relationship between test takers' critical thinking ability and their performance on the reading section of TOEFL. Journal of Language Teaching and Research, 1, 6:830-837.

[6] Gao, F. (2014). Social-class identity and English learning: Studies of Chinese learners. Journal of Language, Identity, and Education, 13, 2:92-98.

[7] Ghaedi, Z and Jam, B. (2014). Relationship between learning styles and motivation for higher education in EFL Students. Theory and Practice in Language Studies, 4, 6: 1232-1237.

[8] Ghavamnia, M., Kazzaian, Z., \& Dabaghi, A. (2011). The relationship between language learning strategies, language learning beliefs, motivation, and proficiency: A study of EFL Learners in Iran. Journal of Language and Teaching Research, 2, 5:11561161.

[9] Hiew, W. (2012). English Language Teaching and Learning Issue in Malaysia: Learner's Perception via Facebook Dialogue Journal. Journal of Arts, Science, and Commerce, 3, 1:11-19.

[10] Kafafi, S. E. (2012). Assessment: The road to quality learning. World Journal of Science, Technology and Sustainable Development, 9, 2:99-107.

[11] Khamkien, A. (2010). Factors affecting language learning strategy reported usage by Thai and Vietnamese EFL Learners. Electronic Journal of Foreign Language Teaching, 7, 1: 66-85.

[12] Macaro, E. (2001). Learning Strategies in Foreign and Second Language Classroom. London and New York: Continuum.

[13] Nikoopour, J., Salimin, S., Salimian, S., \& Farsani, M.A. (2012). Motivation and the choice of language learning strategies. Journal of Language Teaching and Research, 3, 6:1277-1283.

[14] Pan, Y. (2009). Test Impact: English Certification Exit Requirements in Taiwan. TEFLIN Journal, 20, 2:119-139.

[15] Philips, D. (2001). Longman Introductory Course for the TOEFL Test $\left(2^{\text {nd }}\right.$ ed). New York: Pearson Education, Inc

[16] Reynolds, C. R, Livingston, R. B, \& Wilson, V. (2006). Measurement and Assessment in Education (2 $2^{\text {nd }}$ ed). New Jersey: Pearson Education International.

[17] Ruesch, A., Bown, J, \& Dewey, D. P. (2012). Student and teacher perceptions of motivational strategies in the foreign language classroom. Innovation in Language Learning and Teaching, 6, 1:15-27.

[18] Shin, H, (2014). Social class, habitus, and language learning: the case of Korean early study-abroad students. Journal of Language, Identity, and Education, 13, 2:99-103.

[19] Sindkhedkar. (2012). Objectives of teaching and learning English in India. Journal of Arts, Science \& Commerce, 3 (1):191194.

[20] Sugita, M. \& Takeuchi, O. (2010). What can teachers do to motivate their students? A classroom research on motivational strategy use in the Japanese EFL context. Innovation in Language Learning and Teaching, 4, 1:21-35.

[21] Vandrik, S. (2014). The roles of social class in English language education. Journal of Language, Identity, and Education, 13, 2: 85-91.

[22] Warfield, W., Laribee, R., \& Geyer, R.W. (2013). Examining Results and Establishing Benchmark Data from the TOEFL ITP Test. American Academic \& Scholarly Research Journal, 5, 3:191-198.

[23] Wong, R.M.H. (2013). An investigation of strategies for student motivation in the Chinese EFL context. Innovation in Language Learning and Teaching, 8, 2:132-154.

[24] Zareva, A. (2005). What is new in the new TOEFL-IBt 2006 test format? Electronic Journal of Foreign Language Teaching, 2 , 2:45-57.

Murni Mahmud, graduated from IKIP Ujung Pandang, Indonesia in 1991, finished her Master Degree at American Studies Graduate Program, Gadjah Mada University, Yogyakarta, Indonesia 1999, and did her Ph.D. at Anthropology Department, the Australian National University, Canberra, Australia, 2008. She is a lecturer at English Department of State University of Makassar (UNM), at the Faculty of Languages and Literature. She teaches Linguistics Anthropology, Sociolinguistics, Discourse Analysis, English Literature, Linguistics, and TEFL. 